\title{
Review
}

\section{The Concept in Crisis: Reading Capital Today}

\author{
Nick Nesbitt (ed.) \\ Duke University Press, Durham, 2017, x + 320 pp., \\ ISBN: 9780822369622
}

Contemporary Political Theory (2019) 18, S106-S109. https://doi.org/10.1057/s41296018-0190-y; published online 18 January 2018

Celebrating the 150th anniversary of Marx's Capital and the 100th anniversary of Russian Revolution this year, Nick Nesbitt's multi-authored edition The Concept in Crisis is a timely contribution to, and certainly part of, a contemporary contestation and lively revival of critique of neoliberal capitalism in the twenty-first century. Marxism, not long ago considered to be defeated or even born dead, is fuelled here by a renewed sort of reading Marx. As Warren Montag calls it, this project is about reading Althusser reading Marx (p. 167). It seems to owe much to a hermeneutic awareness of endless disputes between sectarian text exegeses and eclectic political doctrines in the historical past of Marxism. A more self-reflexive hermeneutic and its suggested double-layered reading of Marx, by contrast, promise a way out of dogmatism of any kind. Typically, it considers the act of reading not a mere cognitive operation, but a theoretical problem. The publication of Reading Capital in 1965 by Althusser, Balibar, Establet, Macherey and Rancière was significant in this regard. The essays collected in Nesbitt's volume readdress the issue of the act of reading in the Althusserian context, relocate it in reading Reading Capital itself and examine its political impacts in Western Europe and Latin America.

Usefully, the book is divided into three sections investigating textual, contextual and temporal aspects of Althusser's Reading Capital: (1) Reading Reading Capital, (2) Reading Capital in Context and (3) Reading Capital Today.

The first section opens with Alain Badiou's take on Althusser's definition of theory. A theory, Badiou argues, is a systematic organisation of concepts with a certain scientific discursive order. The 'semantic unities of a scientific construction' make up 'concepts'. Theory, being strictly 'scientific', is to be distinguished from ideology and philosophy. As a system of 'subjective' political values ideology employs 'notions'. The term 'category', by contrast, is reserved for philosophy as a business of abstraction and generalisation. A term like 'communism', however, can be a concept, notion and category with regard to its scientific, ideological and philosophical aspects (p. 25). Badiou writes that this necessary threefold distinction was never made by Althusser.

(C) 2018 Macmillan Publishers Ltd., part of Springer Nature. 1470-8914 Contemporary Political Theory Vol. 18, S2, S106-S109 www.palgrave.com/journals 
Following Althusser's slogan to return to the original texts of Marx, reading him in his own words, 'read Capital to the letter' and reading it not only in French but also in German and English (pp. 35-36), Robert Young asserts that Marx's process of rewriting some parts of Capital in the German and French editions as well as Engels's editorial interventions prove that, when looking for an authentic Marx, we encounter rather Engels giving voice to Marx, or Marx rereading and rewriting himself. Accordingly, the authorial and editorial histories of Capital exemplify what Althusser has called rereading, retranslating and finally rewriting the texts of Marx (p. 45).

Emily Apter goes so far as to claim that there is nothing unusual about the openended or incomplete character of Marx's magnum opus. In fact, it is Marx's own intention to develop a dynamic conceptual system that takes the incomplete character of its subject: capitalist mode of production. Apter suggests, using the verb to incomplete in the active sense: 'Marx incompleted Capital' (p. 60).

If Marx's conceptual system is to represent a progressing social mechanism, Knox Peden asks, how should we start analysing it? Should we start, say, with facts or the internal relations? Peden tells us that priority of the starting point of the analysis is not an issue in Althusser. On the contrary, Althusser aims to eliminate the question of priority for it endangers any systematic approach to conceptualising capitalism in its entirety. Grasping 'a unity without any sense of whence the unity is bestowed' or 'treating the part as the whole' is the worst, if not the only, enemy of science. It is fetishism (p. 80).

In the second section, Balibar offers a comparative analysis of Althusser's and Mario Tronti's readings of Capital. Tronti, one of the pioneering figures of the Italian Operaismo movement, published his Operai e capitale in 1960s. Balibar suggests that Althusser and Tronti represent two antithetic Leninist readings of Marx. While Althusser is an orthodox anti-Hegelian critic of Lukács and of his conception of proletariat as the subject-object of history, Tronti is deeply influenced by, and consistently attached to the ideas in History and Class Consciousness. Despite their difference in configuring the interplay of class structures, Althusser and Tronti both illustrate "symmetric returns to the previous history of twentieth-century communism with the hope of "leaping" beyond their historical and theoretical limitations' (p. 100).

Bruno Bosteels problematises the concept of Althusserianism with regards to Che Guevara's understanding of uneven development. Unevenness, a necessary moment of historical leaps, 'is the most general of historic process' both in nature and society (p. 125). Guevara, barely an ally of Althusser, believes that unevenness applies to nature alone, and not to any dominant social system. Elsewhere he questions Althusser's Maoist universalism of contradiction and overdetermination (p. 122). Althusser's universalism risks ignoring particular and exceptional historical and social conditions (p. 123). A more widely circulated name for one kind of problem Guevara detects in Althusser is what Adrian Johnston calls

(c) 2018 Macmillan Publishers Ltd., part of Springer Nature. 1470-8914 Contemporary Political Theory Vol. 18, S2, S106-S109 S107 
Naturdialektik (p. 190). It is about the old problem of whether dialectics applies to both nature and society. His seminar on Philosophy and the Spontaneous Philosophy of the Scientists with an appendix on the Nobel laureate Jacques Monod involves this issue. Curiously enough, in the figure of Monod, Althusser, we are told, glimpses 'a spontaneously dialectical materialist biology in which objectively real "emergences" in nature resembling the dialectics of "quality" and "quantity” in Hegel's Logik' (p. 206).

In the last section of the book, Nina Power offers a feminist reading of Althusser. The concept of reproduction, a major concept in Marx's political economic theory and a central concern of Althusser's readings of it, embodies another case for symptoms present in Althusser's take on Marx. By speaking of reproduction of a certain political ideology and its economic conditions of possibility, Power argues, we run the risk of neglecting some of the major processes, such as the feminine contribution to the process of reproduction in capitalism (p. 222). Althusser's reading of Marx ignores the importance of 'reproduction of human beings' as the 'foundation of every economic and political system' (p. 224).

Nick Nesbitt emphasises the non-empirical quality of method of conceptual construction in Althusser's philosophical reading of Marx (p. 235), and points at another 'full gap' in Lire le Capital, the question of invisibility of value concept as a problem, 'a problem that has only today become perceptible and even crucial for any contemporary critique of political economy' (p. 240). The non-empirical character of value concept is at stake rather than its economic content. Some supporting argument is found in Rancière, who underscores that 'Marx's revolution does not consist in historicising the categories of political economy. It consists in making of them a system... his system makes apparent a structure that can only be understood in the theory of the development of social formations' (p. 243).

The book closes with Fernanda Navarro's Vive La Crise! As this slogan indicates, Navarro speaks here of a crisis today in the sense of a chaos and catastrophe, on one side, and of a new revival and transformation, on the other. Navarro draws attention to a parallactic link between text and political practice. Social realities always go hand in hand with unnoticed possibilities of, and are pregnant with, social change and transformation. She proposes to take 'possibility' as a theoretical and practical category seriously and suggests paying a greater attention to how it operates at a micro-scale. With this turn to micro-possibilities, she believes that social movements or processes 'should be not centralized but local, not international but regional, finding their unity in objective intersecting lines, by communitarian forms with transversal relations' (p. 291).

This volume is representative of contemporary Althusser scholarship and creative returns to Marx. As far as the editor's view is concerned, we are expected to believe that the modern labour movement and revolutionary socialist struggles are 'out' and philosophy as the new subject of anti-capitalist politics is 'in'. If this is true, then the Latin American and West European histories of struggle mentioned

S108 (C) 2018 Macmillan Publishers Ltd., part of Springer Nature. 1470-8914 Contemporary Political Theory Vol. 18, S2, S106-S109 
in the book are of an antiquarian interest. They are practical moments of a grand theory of capital. Young Hegelianism seems to make a comeback here - rather than Marx. Alternatively, we witness in Nesbitt a symptomatic reversal of Marx's 11th thesis on Feuerbach: people have tried to change the world in various ways; the point is to interpret it.

Kaan Kangal

Nanjing University, Nanjing 210008, China

kaankangal@gmail.com 